\title{
FROM THE THEATRICAL TO THE AESTHETIC HERO: ON THE PRIVATIZATION OF THE IDEA OF VIRTUE IN DAVID'S BRUTUS AND SABINES
}

\author{
STEFAN GERMER AND HUBERTUS KOHLE
}

In the opening lines of his Emile, published in 1762, Jean-Jacques Rousseau recalls Plato's Republic. The Greek philosopher's work is said to be the finest ever published on education. According to Rousseau a public education following the Greek example was no longer possible in his own time, since conditions had fundamentally changed. 'L'institution publique n'existe plus, et ne peut plus exister, parce qu'où il n'y a plus de patrie il ne peut plus y avoir de citovens. Ces deux mots, patrie et citoyen, doivent être éffacés des langues modernes. ${ }^{1}$ Unlike in antiquity, when morality was defined as private consent to public demands, Rousseau understands morality as an agreement with 'la nature', that is, with oneself. Rousseau's abandonment of the model of antiquity is part of the bourgeois search for oneself, which conceives of the public sphere as the generalization of personal experience and distinguishes itself categorically from the classical definition of the realm of politics. ${ }^{2}$

It is the aim of the present essay to investigate the consequences of this consideration for the production and reception of 'history painting' and, in using the particular example of two paintings by J.L. David, to render manifest the implications of such new notions as far as both form and meaning are concerned.

Fifteen years after the first publication of Emile, in 1777, the Directeur Général des Bâtiments du Roi, the Comte d'Angiviller, required history painters to represent exemplary virtues taken from events of ancient and modern history. This requirement fits into the context of the reform of "history painting', and corresponds to postulates such as those advanced by the treatises of enlightened art criticism, in particular those of La Font de SaintYenne. Yet at the moment of its formulation this demand was already anachronistic: its premises (i.e. the comprehension of the essence of politics as developed with the classical model in mind, as well as the concept that history presents examples for life) have been replaced by new, specifically bourgeois conceptions. ${ }^{3}$ A report concerning the Salon of 1777 gave an account of the

Art History Vol. 9 No. 2 June 1986

(C)RKP $1986 \quad 0141-6790 / 86 / 0902-168 \quad \$ 1.50 / 1$ 
abortive attempt to provide new impulses to 'history painting' through a series of representations of virtues, and formulated consequences for future projects:

Le choix des sujets est en général dans le genre tragique [as was written in reference to the paintings to be ordered for the next Salon] afin de voir au premier Salon et l'âme des Artistes et l'effet sur le public qui s'est peu occupé des soins que l'on avait pris de présenter une suitte de vertus. Le croiroit-on plusicurs Artistes avoient si parfaittement oublić le point essentielle qui devroit servir à la base de leurs travaux qu'ils ont fait mettre dans le livret de détails de sujet, mais sans titre, il étoit trop tard pour y remedier lorsque l'on s'en est apperçu. ${ }^{4}$

By omitting titles the painters had undermined d'Angiviller's intention to present the exemplary and thus eternally valid. Through the extensive documentation of the historical conditions (the catalogue entries were in part almost literally borrowed from Villaret's Histoire de la France depuis l'établissement de la monarchie jusqu au reggne de Louis XIV), ${ }^{5}$ which directed the interest of the public towards the unique and unrepeatable, 'history painting' was conceived of not as the representation of the general but of the individual and specific. The meaning of the subject represented was obviously not immediately evident; it was only the specification of circumstances that rendered it intelligible and interesting. The Direction Générale attempted to meet the altered taste of the public by ordering 'sujets tragiques', thus drawing forth a new aspect from traditional themes which was relevant for the present. What one is to understand by 'sujet tragique' or, as it was later called, 'sujet noir', will be exemplified here by means of one painting, which will provide us with the background of David's procedure.

Among the themes proposed for the Salon ever since 1777 no examples explicitly qualified as representing virtues can be found. On the contrary, events from ancient, biblical, French or even non-European history seemed to have been proposed on the basis of their emotional impact rather than for the model they embody.

A typical example of such a scene is offered by Jean-Simon Berthélemy with his Manlius Torquatus, exhibited at the Salon of 1785 (plate 17). As a consul, Manlius Torquatus had to condemn his own son to death, because the son had led a victorious attack in battle without awaiting the proper orders. This was interpreted as a violation of public law. Roman history celebrates Manlius Torquatus' unconditional adherence to principles which are not to be influenced by any personal considerations, be they based on familial bonds or on the achievements of the condemned. Both painter and critics are interested in the presentation of the conflict between civic duty and personal desires rather than in the depiction of Roman virtue. In his Emile Rousseau had distinguished between the public role ('habit') and the real essence ('personne'); he established that the intrinsic qualities were those acquired 


\section{FROM THE THEATRICAL TO THE AESTHETIC HERO}

through private socialization, and he criticized traditional historiography for unilaterally stressing the public role. A comparable re-evaluation of the private realm led to the new interest in the personal emotions of the protagonist, as we found it in Berthélemy. Indeed Roman historiography had also thematized the conflict between individual inclination and devotion to principles, yet there the dice were always loaded in favour of the public interest. For the painter as well as for the critics the fundamental priority of the public domain was no longer valid. On the contrary, the Roman ethic was conceived of as 'atroce', the father was branded as a barbarian, and the solution provided for the conflict appeared in dissonance with the sensibilities of the time and as a violation of the precepts of 'nature'. The interest focuses, therefore, on the subjective, dealing with a moral conception which is experienced no longer as necessary but indeed as questionable. One becomes interested in the psyche of the protagonist; the painter is required to represent in a believable way not so much the father's decision but the difficulty of deciding.

On voit combien il est déchiré [as we find in a discussion about the father] de l'ordre qu'il va donner, et cependant il le donne; c'est ainsi qu'il faut que le peintre cherche à produire des grands effets par le contraste et les oppositions, et qu'il adoucisse les sujets qui dans nos moeurs ne pourroient inspirer que l'horreur et la férocité.'

Psychologization here appears as the one and only way of extracting topical interest from a theme grown unfamiliar; it finds its expression in the concentration upon the emotional reactions of all the protagonists. The son stands, calm and composed, in front of his father. His attitude is in contrast to the violent outbursts of the soldiers who accompany him and to those of the figure in the background. Berthélemy thus increases the tension: from the serenity of the son to the imploring soldiers and finally up to the father who is sitting on a platform. The latter is presented by Berthélemy as a torn figure, expressing physically the conflicting interests: his outstretched right arm orders the carrying out of the execution, his head, however, is turned away. His left hand clutches his heart. Here we encounter a hero dismayed by the consequences of his own decision. The representation of the afflicted hero was understood by some critics as a successful adaptation. Others implicitly recognized the modernity of the solution, as they criticized the fact that Berthelemy had given by no means the image of a Roman hero, since they felt that such a shaken figure would never have been in a position to pass the verdict. We have indeed here the image of a modern hero, a hero who does not master the situation but is its victim. In this way the attempt is made to grasp the dilemma of the classical conception of morality through pictorial means. That Berthélemy did not completely succeed in his task is manifest in the contemporary criticism raised against him, that his painting was theatrical. The reproach of theatricality aims at the inadequacy of content and form; it certifies that the scheme of composition - which Berthélemy had, by the way, borrowed from Titian's Pesaro Madonna - succeeded only partly in rendering the sentimentality of the 'sujet'. ${ }^{8}$ In its escalation of emotions the composition implies a steadfast and unswerving hero, yet reveals a figure just as shaken as 


\section{FROM THE THEATRICAL TO THE AESTHETIC HERO}

all others, embodying not the necessary rigour of civic duty but the personal horror at the fate to which the son was doomed. Put another way, the composition prepares the way for a hero who is at one with necessity, and instead encounters one desperately opposing it. Facial and gestural expression constitute to some extent the outcry of the private against the public role demanded by the composition. This forces the artist to exaggerate cxpression even to the point of jeopardizing the verisimilitude. Psychologization alone - as becomes evident from this example - managed to discover a modern aspect in this traditional theme. Still it was incapable of endowing the subject with an adequate form.

A new convincing solution can only be achieved by changing the whole structure of the picture. The representation of the inner conflict has to be freed from its ties to the physical expression of the protagonists and become the task of all means of composition. This means doing away with certain compositional schemes. (The role of 'ligne pyramidale' and 'marche de la lumière', as are examined by Puttarken, ${ }^{9}$ may be recalled.) The notion that painting should give us the illusion of reality itself, as it was still sustained by Laugier, ${ }^{10}$ is replaced by a conception, which gives painting the task not of imitating but of pictorially constituting meaning, thus defining painting as autonomous, i.e. not necessarily dependent on external reality. A comparatively early attempt to load the structure of the entire picture with meaning, Doyen's Ulysses and Andromache (plate 18; Salon 1763), had to fail, because it remained bound to an illusionistic conception. The splitting of the picture into two halves in order to depict an insoluble conflict weakens the effect, since the centre is perceived not as meaningful space, but as a simple void. The space between the figures remains interpretable as part of the setting and not as the expression of the difference between the persons. This is exactly what Diderot criticized in his 1763 Salon. ${ }^{11}$ David's Brutus (plate 19; 1789) presents an example of a picture that frees itself from the conventions of illusionistic painting and through the redefinition of all compositional means conceives of the autonomy of painting as the productive potential to represent the conflict of private and public interests in a credible manner.

III

The Brutus-theme had been brought to public attention by Voltaire's drama on the same topic. For theoreticians such as La Font de Saint-Yenne and Diderot, it served as exemplary subject-matter for a new type of 'history painting' which aimed at the conveying of moral statements. Before David the subject had been dealt with by F.H. Füger and G.G. Lethière. The former had chosen the moment between the sentencing and the execution, as the sons still hoped for pardon, while the latter's theme was the execution itself: one son being already dead and the other recoiling at the sight of his brother's blood. David, too, had originally thought of depicting the execution scene: Brutus and Collatinus, the two consuls, were to sit in front of a temple, the latter covering his face while the father with composed mien watched the execution of his 
sons. The lictors were to have already grabbed the two sons, one of whom was kneeling by the executioner's block, imploring the father's mercy, while in the background ${ }^{12}$ other conspirators were being brought in. Contrary to tradition and disregarding his original conception, David decided not to represent the public appearance of the consul but instead to locate the scene in Brutus' house, in order to focus on the father's personal reaction. We are already acquainted with such a privatization of an antique subject from the Oath of the Horatii - here, too, the scene had been shifted from the Forum to a private house, in order to make possible the confrontation between an heroic decision and its personal consequences. The moment depicted is described in the long title of our painting: The first consul, Junius Brutus, retums home after the condemnation of his sons, who had conspired with the Tarquins; lictors bring in the corpses of his sons, so that he may give them burial. David chooses the moment after the dramatic decision; the subject of the painting is not the struggle between civic duty and private wishes, but rather the terrible consequences of this struggle. Thus the hero's role as a victim becomes explicitly thematized, his dealing with the events is made central, and attention is led away from the action toward reflection. Even in his first sketches David was already interested in showing Brutus, absorbed and alone, sitting in the front left-hand corner of the painting. A group of several onlookers oriented towards Brutus was planned for the right half of the painting. Soon, however, the group of mother and daughters was developed out of this motif, thus producing an accent equivalent to the consul's figure. The attention of the group on the right was led away from Brutus through the introduction of the lictors who enter from the left, so that the isolation of the protagonist was intensified. After positioning the separate groups David had then to deal with the problem of linking them spatially. He introduced first the columns of the atrium, of which the one behind Brutus set him apart from the rest of the action; the lictors became visible between the first and second columns; another group of onlookers appeared in the semi-circle surrounding mother and daughters. The solution finally given in the painting simplifies and intensifies the composition: the lictors enter through the left doorway, behind the Dea Roma; the draped bier creates a background for Brutus' head. The group of mother and daughters is separated from the consul by the first column of the atrium and a chair whose back is turned to Brutus. The onlookers found in the first sketches have disappeared. Only the figure of the maid remains seated at right. David fills the empty space with sparingly chosen furniture among which the figures are placed. The actions are intensified through simplification. David focuses attention on the group of mother and daughters, while all secondary effects, such as the severed heads of the sons or the weeping face of the maid at right, are eliminated, since they risk distracting the viewer's attention from the main action.

As is gencrally known, ${ }^{13}$ the renunciation of a traditional pyramidal composition and the placing of the main protagonist in the shadow bewildered the academic critics. The conscious infraction of the set conventions must be understood as an attempt to provide a suitable form of presentation for the 'sujet'. David renounced the traditional hierarchies, thus liberating the 
separate elements of the painting, all of which he could therefore use to convey meaning.

The painter has the viewer direct his attention to the secondary figures and places the sewing basket rather than a main figure in the centre of the painting. Both halves of the picture form a contrast of light and shadow as well as an opposition between a static system of vertical and horizontal lines (into which Brutus is inscribed) and a dynamic pair of diagonal lines formed by the contour of the mother's back, on the one hand, and the silhouette of the maid on the other. The left side of the picture combines in a close relicf all the elements of the conflict: behind the insecurely crossed legs of the consul we can recognize a stone relief of the Capitoline she-wolf suckling Romulus and Remus. At the consul's left rises the dark silhouette of the statue of the Dea Roma, on the plinth of which Brutus is resting his elbow, while his head is set off by the bright colour of the shroud behind him. 'Raison d'ctat', personal suffering, the contrast between the little children on the relief of the Capitoline she-wolf and Brutus' dead sons on the bier - all this is conciscly rendered by the pictorial organization, irresolvably linking the protagonists to such elements as render the conflict physically evident. Similarly the group of the mother and daughters compresses horror, aversion and helplessness into one relief composition, thus gathering together in a concentrated space and heightening the impact of the elements charged with meaning. The pressing together of the figures and the corresponding cmptiness of the room, with its sparse furnishing and its oppressive architecture, creates an opposition of themes: the antithesis intended by the division of space becomes evident. Starting from left to right David presents the centre wall of the house with the doorway; then comes a dark corridor which is separated from the inner courtyard by the columns of the colonnade, which encloses the courtyard at the left-hand side of the rear. The vertically accentuated frame thus obtained is completed in front by the massive stone slabs of the floor. The assumption of a high horizon for the receding orthogonals makes the ground appear as if seen from above and, since the vanishing lines of the ground do not fully correspond to those of the lateral colonnade, the ground floor in the foreground, where Brutus is seated, appears to be slipping out of the frame. The result, therefore, is that Brutus does not really sit inside the room but appears rather to sit in front of it. Also the central plane cannot be referred to as space; rather, it is a compact relief scene which stretches from the bier carrying the corpse on the left of the picture across to the first lictor, then to the foremost column of the lateral colonnade, then on to the chair and the table, followed by the group of the mother and daughters and down to the chair in the right-hand corner of the picture behind which the maid is sitting. The lower margin of this relief consists of the fourth horizontal line of the floor. There appears to be no clear delimitation in the upper part of the painting. It is important for the relief effect that the middle zone breaks the spatial development laid out in the floor lines. At the left, the sharp light outlines the bier and the lictor against the dark background without giving them corporeality. The point concerning the flatness of the middle zone becomes clear when one looks at the lateral colonnade: the four columns are so foreshortened that they give scarcely any 
feeling of depth. Moreover, the cloth stretched before the columns stresses the plane surface. Due to the levelling there is no space left in the inner court for figures or furniture. They are all compressed together into a thin strip, more or less taking up the space between the fourth horizontal line and the first column of the lateral colonnade. For that reason the furniture appears greatly foreshortened, so that, even though the relationship between the various elements placed one behind the other seems quite clear, it is impossible to determine precisely where the table is standing. The mother and daughters are compressed into a configuration, the outline of which is clearly distinguished through the background and the laterally adjoining elements. The stress on the individual colours of the composition intensifies the flatness of the composition, so that - in spite of all attempts to represent a spatial graduation of the figures in relation to each other - they remain consistently flat.

Illusionistic painting strives to convince us that it reflects as faithfully as possible events that have occurred outside the realm of painting. David breaks with this conception: the entire composition of his picture constantly calls to mind the fact that the depicted exists only inside the realm of painting and only as a result of the consequent use of pictorial means. The events depicted are not documented but constructed: reality exists only as fiction. ${ }^{14}$ The relationship between the whole and the elements composing it, as well as that between the elements themselves, is thus essentially transformed. The parameter for the organization of parts is no longer the hierarchy of the real, but rather the requirement of the painting itself. The context alone endows the individual elements with meaning and results only from the pictorial organization. In comparison with the protagonists of Berthélemy's picture, what strikes us in Brutus is the reduction of gestural and facial expression. David developed Brutus' attitude from one of passive, introvert brooding (where the consul supported his head on his right hand) and gave a peculiar twist to his figure, so that the lower part of his body appears in profile and turned to the left, whereas the upper part of the body and the head are frontally directed towards the viewer. The face had originally been lowered, looking down, or even covered by the hand raised to the head; now, however, Brutus is emptily gazing at the viewer without really seeing him, and his hand has been removed from his head, so that the consul appears as if suddenly roused from deep thought. In comparison to the vehement emotional outburst of his wife and daughters, Brutus is shown calm, but not attentive. He looks petrified, as if through the mere entrance of the lictors the full extent of the tragedy that had occurred had become apparent to him. The emptily staring eyes, the uncertainly placed feet and the peculiar twist of the body betray the - fact that Brutus' calm is not of a stoic but rather of an apathetic nature, namely, that he is not master but victim of the situation. As opposed to Berthélemy, David is capable of making do with a minimum of emotional expressiveness, since he frees his protagonist from the burden of having to embody all the contradictory strains simultaneously. The conflict between civic and private interest becomes evident through the linking of the Capitoline shewolf, the Dea Roma, and the bier in one relief unit with Brutus. One critic has registered with irritation that the Dea Roma is not directed towards the room 
within the picture but rather towards the viewer. ${ }^{15}$ This criticism can be justified only if one conceives of this statue as a mere 'accessoire', as a means of giving the room the aspect of a Roman interior. If, however, one considers that David was not interested in authentically rendering the image of Roman house idols but was aiming rather at manifesting conflicting forces, it then becomes clear that the orientation of the Dea Roma towards the viewer is part of the signification process. Whereas Berthélemy had to embody all conflicting forces, Brutus is freed from this task because the individual elements of the interior take on meaning. The same critic also took objection to the choice of the scene of action; since, as he knew from antique examples, burials in republican Rome took place outside the city walls, it would have been inconceivable that the sons would be brought back to their father's house.

Precisely this choice of the scene proves how little the documentary description of an historical event mattered to David. It was rather its pictorial mise-en-scene that interested him. He selected the moment after the execution since he was fully conscious of the capabilities of his medium and knew that the moment of the greatest emotional tension (which was the one chosen by Berthélemy in his depiction of the conflict of decision-making) actually curns out to be the least picturesque. As soon as painting gives permanence to the state of highest tension, it automatically weakens that state and risks rendering it theatrical. On the other hand, the decision to depict the contemplation of the consequences of an irrevocable decision represents a clear recognition of the limits of the pictorial medium, since it leaves the undepictable to the imagination of the viewer. The transposition of the greatest emotions to the secondary characters is similarly explainable: it frees the protagonist from having to express pain over the loss of his children. The women entirely give in to their emotions, thus providing a contrast to Brutus' immobility.

The novelty of David's procedure was recognized by all the critics, including the academic ones. Some critics grasped, moreover, that the production of significant meaning in this painting resulted from the contrast and combination of pictorial means. Where the psychologizing 'sujets tragiques' had failed in actualizing the moral themes which had grown unfamiliar, David's strategy succeeded.

Pour apprécier les beautés sublimes de cette composition, il faut se transporter au temps où Rome faisait consister sa liberté dans la rudesse de ses moeurs; au temps où les prétendus citoyens ne détronoient les Rois que pour régner eux-mêmes: au temps où les sentiments de la nature cédaient à l'ardente ambition: au temps où un fantôme républicain conșolait le Peuple des tyrannies de ses consuls

a critic claims, refuting in the name of enlightened 'nature' Roman morality, as was customary in the tradition of 'sujets tragiques'; yet he continues:

originalité de projet, puisque le sujet principal se trouve dans l'obscurité du tableau comme pour marquer la douleur d'un être que la morgue républicaine ne saurait empêcher d'être père. En effet, cette production est plus d'un grand Poète que d'un Peintre: et le reproche que j'ai entendu 
faire de voir deux tableaux dans ce sujet, il est justement la cause de mon admiration. Je crois apercevoir $J$. Brutus, s'éloignant de sa famille, mais ne se reprochant pas encore sa sévérité: je crois le voir balancer entre la nature et l'ambition. ${ }^{16}$

Another critic notes: 'L'idée d'avoir placé Brutus absolument dans l'ombre est un trait de génic qui contribue à rendre sa figure sinistre et à faire valoir le groupe intéressant que forment la mère et les soeurs de ces malheureuses victimes de la sévérité paternelle. ${ }^{17}$ Formal means are understood by these critics as significant components; with the suppression of the usual hierarchies which were directed at the hero, the subordinate figures are drawn into view as carriers of meaning in their own right.

Meaning is constituted by the interrelation of formal elements, and it remains the viewer's duty to interpret it. Unlike Berthélemy's painting, Brutus demands interpretation, as opposed to simple reading. ${ }^{18}$ This orientation towards a reflexive appropriation was already determined by the decision to show, not the event itself, but rather its personal consequences. In other words, it was determined by the choice of place and time. It was also reinforced by the absence of gestural and facial reaction on the part of the protagonist: only the subordinate figures are unequivocal in their emotions. Brutus' feelings must be reconstructed on the basis of the viewer's own experience. As stated above, the organization of the picture conceives of the limits of the medium which dictate that the representation of extreme situations be renounced as a productive possibility to intensify that which is represented. This means realizing that the representation of extreme passions does not necessarily arouse the viewer, and that reception and production are two differently structured processes. The representation may, therefore, not rely on the mere presentation of a given type of passion, but instead must structure its figures so as to give the viewer the possibility of enlivening the events by means of his own emotions. Radical subjectivization dissolves the traditional conception of 'history painting'. There exists a prototype for such a process: it is Reynolds' Ligolino (plate 20). Reynolds shows the figure of Ugolino independent of Dante's Inferno; for him Ugolino is merely the suffering father of innocent children condemned to starvation. Like Brutus, Ugolino sits left, motionless in the foreground, turned towards the viewer, while at right an agitated, emotionally troubled group is formed by the Count's sons. The choice of the moment depicted is similar: Reynolds does not show us the Count's madness which became a favourite subject of nineteenth-century painting, he shows the instant where Ugolino hears the bolting of the tower's doors and suddenly becomes aware of the consequences of the situation. His reaction is not an outburst. As in Dante, he turns to stone. The essential event takes place inside him. There is no interaction between Ugolino and his children. The frightened glances and movements of the children receive no answer from the father. Only the viewer knows, like Ugolino himself, what the outcome of the event will be: the gaze of the Count is directed at him. The interpretation of this painting - like that of David's Brutus - necessitates entering into the psyche of the protagonist, completing through the imagination that which is not represented. 
Diderot had sketched in his Paradoxe sur le comédien (1769) a similar inclusion of the viewer which presupposes the distinction between the process of reception and the one of production. As with David, so too Diderot acknowledges the autonomy of the work of art, thus conceiving of it as an entity distinct from nature. Passion on stage is no sudden outburst, but rather the result of the calculated use of theatrical means. Not the excitement but rather the distance of the actor is necessary for convincing acting. Only a radical separation of the means of production from reception cnables the spectator to be moved; only stylization according to the conditions of the medium guarantees verisimilitude and persuasive power. ${ }^{19}$ By limiting what is represented, the imagination of the recipient is left free to complete it.

In its reference to the viewer, the context in which the latter views the picture becomes an important elcment in its interpretation. From David's letters and the reactions of the critics at the Salon of 1789 we know that the painting was not intended as a political manifesto, nor was it understood as such at the time of its first appearance. ${ }^{20}$ As with the 'sujets tragiques', interest was directed at the inner conflict of Brutus, and the moral was experienced as 'atroce', i.e. bevond one's own experience. The painting was understood as the perfect representation of the hero as victim, not as a glorification of republican virtue. In the course of the Revolution - starting with the success of Voltaire's drama in 1790 - the Roman consul became a positive figure, at first as a decided defender of the 'patrie', later as an example of a dedicated fighter against royalist machinations. In this context the evaluation of the protagonist of David's picture changes. A criticism of 1791 helps to demonstrate this change:

Brutus, ta vertu te coûte cher, mais tu devois cet exemple à tes concitoyens.

Comme il est sombre! comme il est accablé de douleur! Ah! voilà ses

funérailles, famille désolée, soeurs sensibles, versez, versez des torrens de

larmes. Rome vous plaint, mais Rome fait inscrire ces mots sur le marbre:

A Brutus qui sacrifie ses enfants la patrie reconnaissante. ${ }^{21}$

The evaluation, even the understanding of the conflict represented in the 'sujets tragiques', depends on the relevance one is prepared to give to the choice between civic duty and private wishes. To the French of the 'ancient régime' the public demand must have appeared strange, cruel and incomprehensible, since they could not assign any correlative to the public realm in its political and social reality. ${ }^{22}$ At best, the French could conceive of the public demand as the fate which befalls the protagonist. In the 'sujet tragique' the abstract conflict has a concrete, namely private, content: it is described as a struggle between 'nature' and necessity and is represented with its focus on the psyche of the protagonist; this focus can be based on the viewer's experience of privacy. For such an interpretation the process of dealing with the conflict is more interesting than its moral message. With the sentimentalization of the hero the individual experience of privacy triumphs over the general demands 
of the public realm. By breaking away from conventions of composition, David resolved the dilemma of the 'sujets tragiques' in turning to a radical privatization of the subject. That is the reason why his critics were able to appreciate his painting as a successful fulfilment of the intentions of 'sujets tragiques'. Only the Revolution replaced the abstract notion of the public realm with the concrete one of 'patrie'. Through this replacement, the sacrifice of the sons (which until then had appeared merely as a cruel act on the part of Brutus) appeared to the viewer as a necessary decision in favour of the interests of their fatherland. This decision was understandable to viewers on the basis of their own experience. In the revolutionary context Brutus' action regained its original greatness. With a sense for the situation the abovementioned critic visualized Rome setting up a monument to Brutus. This monument would bear exactly the same inscription as was affixed to the church of Sainte Geneviève which was turned into a Pantheon for the revolutionary heroes: 'Aux grands hommes - la Patrie reconnaissante'. The reevaluation of the public realm brings the private sphere under suspicion for providing a space for the articulation of dissident (which per se means counterrevolutionary) interests. Brutus must condemn his son for the benefit of a positively defined public realm. The re-evaluation of the figure of Brutus during the revolutionary period does not mean that the hero's relativity is suspended. As with all the heroes of the Revolution, so also the appreciation of Brutus remains tied to the situation. The fact that according to the circumstances Brutus can be seen as either a pitiable private victim or an example for civic behaviour proves that his action no longer has the permanent validity of a model case.

W. Kemp has observed that David in his Oath of the Jeu de Paume does not give an authentic representation of the revolutionary mass, but a representation of a gathering of individuals who abstain from complete submission to the volonté générale." We can take this as a hint that in revolutionary French painting the primarily individualistic spirit of the day has only superficially been covered up by an ideology which puts the stress on community. ${ }^{23}$

When meaning no longer precedes the work of art but is constituted by the beholder through the interpretation of the formal relationships, its understanding becomes dependent upon the changing historical situation. As a reaction to the political changes which had personally befallen him in the form of prosecution and incarceration, David devised the concept of an art which stands above circumstantial alterations. His earliest considerations of the Sabines arrêtant le combat entre les Romains at les Sabines occurred in 1794, a time when David's position was endangered, his political world discredited and his artistic reputation questioned. When, in 1799, the painting was finished, David had become head of the leading atelier of Paris and the focus of a group of students who collected all his sayings and venerated them as a doctrine of Beauty. Both the renunciation of politics and an enthusiasm for disinterested 
beauty are manifestations of the post-revolutionary period and influence the painting we are now to discuss. With this painting (plate 21) David attempts to determine anew the social role of art. The choice of theme is particularly interesting, since it deviates from tradition: instead of the rape of the Sabinc women, David represents the Sabine Hersilia separating the fighting Romans and Sabines. The artist explained in a leaflet composed for the visitors to the exhibition that the Sabines, furious about the abduction of their daughters, had invaded Rome three years later to take revenge. A violent battle ensued, till the women, by then mothers of Roman children, interceded and enforced a reconciliation between their quarrelling fathers and husbands. David isolates a few figures from the mass of those involved in the action and places them like a relief as personifications of contradictory, conflicting interests before the background formed by the other participants. The figures have no space to act. They are connected in a row on the surface and impress us less as active agents that as part of a compositional arrangement. One critic ${ }^{24}$ compared the picture with Poussin's Rape of the Sabine Women and remarked that whocver had seen Poussin's painting knew in what manner the abduction must have taken place, whereas David's picture left nothing 'dans l'imagination que la trace de quelques figures confuses'. The non-academic lay-out makes it difficult for critics judging on the basis of traditional criteria to understand the work. For example, one critic was puzzled by the general at the right who puts away his sword, since he is too far away to have heard Hersilia's words of peace. ${ }^{26}$ The critic expects a sequence of events; he looks for cause and effect, main plot and subplot. David, however, suspends the time sequence and replaces it with simultaneity, so that the general's action is not a consequence of the action in the foreground but rather an attributive part. The same is true for the other evidence of reconciliation such as the gesture of the commander at the left, ordering the cessation of belligerence, or the actions of the soldiers in the centre, as they throw their helmets up in the air in a show of joy over the peace agreement. Parallel to Lessing's Laokoon thesis, David seems to have transformed temporal succession into simultaneity, thus accepting the specific limitations of his medium. ${ }^{27}$

As in the background scenes, action in the foreground is suspended. It is not the 'moment heureux' at the climax of an action that is represented, but the permanently frozen stance of the figures. Each move on the part of Romulus corresponds to a counterpoise of Tatius'; both figures maintain the equilibrium by balancing the tension in every detail. The figures are not really engaged in combat, they merely pose: ${ }^{28}$ David has united single figures into a group; none of them performs independently but appears as an element of pictorial disposition. The artificiality of this configuration is manifested by two means: through borrowings and the use of the nude. Already the early critics sought to find models for the protagonists in the history of art: 'Tatius existe sur un candelabre antique', Romulus would correspond to a 'guerrier tracć sur un vase étrusque', Hersilia would be 'imitée d'après Raphacl. ${ }^{, 29}$ It is a matter of indifference whether the identifications are correct in each particular case: the procedure has been properly recognized for what it is. We have here indeed a repertory of figures made available to us through the history of art which is 
subsequently used in a context different from the original one. David himself had described this practice of borrowing to his students as central to his purpose. In so doing he distinguished various forms of borrowing (of an entire composition, of a gesture, of a figure type) and justified the procedure with an allusion to the ancients, who had placed greater value on the perfecting of art through the improvement of the known rather than on the invention of new notions. ${ }^{30}$ David describes the procedure as a conscious stylistic choice, a transition from Roman to Greek art. He is more interested in creating a work of art following the model of the ancients than in depicting an event. With the periodization of antique art and the outlining of its evolution the old topos of imitation of antiquity became shaky and was supplanted by the necessity to select one particular period for a model. Already in 1788 Quatremère de Quincy had recognized the problem and demanded that whoever wanted to imitate Antiquity should possess solid and precise knowledge of history, in order to be able to choose as his model an epoch of perfection rather than one of decay. ${ }^{31}$ David justified his procedure in similar fashion: he wanted to return to the sources of art, its pure Greek form. Like the Grecks themselves, David wanted to use nude figures and unharnessed horses in his painting. The nudity of the figures was intended to amaze the vicwer and render the picture recognizable as a combination of several works of art. Asked by an 'amateur' about the nudity of the figures, an 'elève' answers that naked figures, appear on antique medals and basreliefs. The 'amateur' agrees, noting, however, an important difference: 'En effet, ils sont représentés nus, mais isolemment et non pas en action. ${ }^{32}$ David does not introduce his figures in order to create a continuity of action, but rather in order precisely to dismiss the action through aesthetic stylization. He removes all references to a progressive sequence. He was not interested in the criticisms regarding the absence of the signs of a violent battle nor was he bothered by the demand for a more precise localization of the event. ${ }^{33}$

David transforms the historical event into an aesthetic presence and attempts to convey general and permanent validity to the unique by means of stylizing each action. The painting must therefore be necessarily understood as a construction. "On peut considerer ce nouvel ouvrage de David plutôt comme un cadre dans lequel il a renfermé une magnifique collection de suprêmes tableaux que comme un tableau qui mérite d'être placé parmi les chefs. d'oeuvres. ${ }^{34}$ Acting figures are transformed into works of art, heroes into monuments. Unlike in the preparatory sketch, Romulus no longer holds the lance prepared to throw it, but balances it on his fingertips. He presents both his lance and oversized shield ${ }^{35}$ as attributes rather than as weapons. Instead of being depicted directly, the event becomes restructured into a static image according to the possibilities of the medium and the examples of art tradition. That is why Tatius and Romulus appear more restricted in their impetus than they would be could their attitude be attributed to Hersilia's intercession. On the other hand Vincent, David's immediate predecessor in the depiction of this event, really does show a moment of the battle (plate 22). The beholder cannot be at all sure that Hersilia's attempt at reconciliation will succeed.

Even more than in the Brutus David distances himself from recent tradition 
through the reflection on history and the possibilitics intrinsic to his medium. $\mathrm{He}$ in fact decries as 'theatrical' and 'grimacing' his own carly solutions. The painter thus finds in Brutus elements of a narrative structure which contradict a definition of pictorial means in Lessing's terms, since with the entry of the lictors a precise moment in time is given, whereas in the Sabines the time sequence is transformed into aesthetic presence. We would argue that David's emphasis on the aesthetic character is a result of his acquaintance with Winckelmann's writings. ${ }^{36}$ The latter had pointed out in his Geschichte der Kunst des Altertums, published in 1764 , that expressivity detracts from beauty and that 'der Begriff einer hohen Schönheit nicht anders erzeugt werden (könne) als in einer stillen und von allen einzelnen Bildungen abgerufenen Betrachtung der Secle. ${ }^{37}$ Winckelmann puts forward the concept of the minimization of expressivity for the sake of beauty. He opposed his thesis to that of Lebrun's Expression des passions. Indeed Winckelmann accused Lebrun not only of depicting the most extreme degree of passion, but also of escalating passion to the extent of 'Raserey'. Instead of limiting itself to depicting the particular, art should represent the universal in its typical form untroubled by passions. Winckelmann praised the Greek artists for their ability to separate physical and psychic sensations from corporeal expression, and to leave it to the imagination of the viewer to supply the inner emotions of the subject of representation. This is the gist of the following passage:

Ausserdem ist die Stille und die Ruhe im Menschen und bei Tieren der Zustand, welcher uns fähig macht, die wahre Beschaffenheit und

Eigenschaften zu untersuchen und zu erkennen, so wie man den Grund der

Flüsse und des Meeres nur entdeckt, wenn das Wasser still und unbewegt

ist; und folglich kann auch die Kunst nur in der Stille das eigentliche

Wesen derselben ausdrücken. ${ }^{38}$

The paragraph just quoted shows the realization of the dialectics of inner feclings and corporeal expressions even more clearly than the famous formulation of 'stille Einfalt und edle Grösse'. ${ }^{39}$

In the rejection of his own early works under the reproach of 'theatricality', David recognized the impossibility of giving a specific expression to a specific passion. Only stylization according to the classical model is capable of conveying to the figures that universality which renders them accessible to the imagination of the viewer. By transposing the active figures into aesthetic calmness he opened these up to the public's emotions, offering an unrestricted projection screen. Thus he developed a concept of how an autonomous work of art should be read. How much he was interested in this aspect becomes evident from the presentation of the painting. He exhibited the picture apart from the Salon in a special one-picture show, and charged an entrance fee. The procedure was so uncommon that David found himself compelled to justify it by means of reference to analogous undertakings by both Zeuxis and Benjamin West. ${ }^{40}$ Only the exhibition, David explained in an accompanying text, can provide the necessary financial means to enable him to create history paintings with the independence suitable to genius. At the same time this form of presentation provides art with the ability to fulfil its true vocation: "[the 
populace] s'éclairera sur les arts, auxquels il n'est pas si indifférent qu'on affecte de le croire; ses lumières s'accroitront, son goût se formera. . . ."4 Exhibition is the model of the social role of art: it should ensure revenue and recognition to the painter while concomitantly educating a public which until then, due to its social position, had no access to works of art. The intention is to educate towards art, not to educate through art. Autonomous art is thus completed by means of a concept for its adequate reception. The intense dialogue between picture and beholder which an autonomous work of art requires necessitates a form of presentation which distinguishes itself by the isolation of the painting from the distractions of the Salon.

Questioning art's social role is typical for the post-thermidorian period. A commission of the institute to which David belonged formulated this problem as a competition question: 'Quelle a étć et quelle peut encore être l'influence de la peinture sur les moeurs et le gouvernement des peuples?' One of the contributors, George-Marie Raymond, ${ }^{42}$ solved the problem in a fashion similar to David's: he declared it was art's task to form the people's taste and it was for that reason that art was politically important.

The process described here may be defined as the replacement of an illusionistic conception of painting by a fictive one. To sum up: for the enlightened critics antique morality had grown unintelligible since it was felt to be no longer in agreement with 'nature'. The unfamiliar antique morality could only be shown in an interesting way if one concentrated on the inner struggles of the protagonist, thus psychologizing the subject. Berthélemy had undertaken the attempt of such an actualization, yet he tried to represent the inner conflict as action, thus making his painting theatrical. David had grasped that inner commotion may be convincingly represented only through the reduction of physical expression and that therefore it had to rely on the imagination of the viewer for completion. For that purpose the break with convention was of service to him, as it forced the viewer of Brutus to interpret the picture, instead of merely reading it. The viewer thus turns from an unsolicited witness into an active participant in the production of meaning, while at the same time the role of the depicted figures is reduced from that of active agents to that of elements of the totality of the picture. While Berthélemy had shown the climax of an action, David shows the seflection of an action not depicted, thus excluding almost all narrative elements. Yet a remainder of rudimentary time structure is maintained in the selected moment of the entrance of the lictors which serves as the occasion for the meditation on the sons' death. An additional vestige of action is to be found in the emotional outburst of the women.

In the Sabine Women David pushes this idea even further and completely replaces action by aesthetic presence. The figures are frozen into works of art. The beholder has to bear in mind Winckelmann's concept of the separation of inner sensations and outer expression in order to enliven the figures on the 
basis of the viewer's personal experience. As distinct from the figure of Brutus, who could be understood as a positive or negative example, depending on the circumstances, the Sabine Women figures no longer possess a specific content but are instead potentially accessible to the most varied interpretations; because of their artificiality, they may simply be taken as examples of fine art. The renunciation of a specific content is a result of the privatization of the interpretation of works of art which discards politics as possible subject matter. ${ }^{43}$ Unlike Berthélemy, who had tried to represent a specific conflict or at least the intrinsic dilemma of a certain morality, and even unlike his own Brutus, where the reflection concerning a given decision had been thematized, in the Sabine Women David gave up all claim to a common moral denominator and established the universality of the picture in an aesthetic manner. His undertaking characterizes a situation in which moral portents can no longer be given a single specific meaning and in which, therefore, aestheticism is to be grasped as the means of actualizing the individual experience of the beholder.

$$
\begin{array}{r}
\text { Stefan Germer and Hubertus Kohle } \\
\text { University of Bonn }
\end{array}
$$

\section{NOTES}

Assistance in translation is acknowledged from Monika Grünberg-Drocge and Siephen Shearier.

1 J.-J. Rousseau, Oeuvres Complètes, vol. IV, Paris, 1969 (Pléiade), p. 250.

2 Cf. J. Habermas, Strukturwandel der Öffentlichkeit. Untersuchungen zu einer Kategorie der bürgerlichen (jesellschaft, Darmstadt/Neuwied, 14/1983: cf. also Habermas, 'Die klassische Lehre von der Politik in ihrem Verhältnis zur Sozialphilosophie' in Theorie und Praxis, Frankfurt, 3/1982, pp. 48f; R. Koselleck, Kritik und Krise. Eine Studie zur Pathogenese der bürgerlichen Welt, Frankfurt, 3/1979.

3 Cr. R. Koselleck, " "Historia magistra vitae". Über die Auflösung des Topos im Horizont neuzeitlich bewegter Geschichte', in Koselleck, V'ergangene Zukunft, Frankfurt, 3/1984, pp. 38ff.

4 Archives Nationales o $1925 \mathrm{~B}^{12}$; quoted in G. Sprigath, "Themen aus der Geschichte der römischen Republik in der französischen Malerei des 18. Jhdts. - ein Beitrag zur Ikonographie des 18. Jhdts.', dissertation Munich, 1968, p. 133; Sprigath has published a number of sources related to our subject.

5 E.g. Brenet's Mort du DuGuesclin. The description in the livret is based on Villaret's Histoire de la France depuis l'établissement de la monarchie jusqu'au règne de Louis XIV, vol. XI, Paris, 1763, pp. 55ff. Cf. also M. Sandoz, 'Nicolas-Guy de Brenet. Peintre d'histoire', in BSHAF, 1960; Paris, 1961, pp. $33 \mathrm{ff}$.

6 Sprigath, op. cit. (note 4), p. 154.

7 Ibid., p. 326.

$8 \mathrm{Cr}$. T. Crow, 'The Oath of the Horatii in $1785-$ Painting and Pre-Revolutionary Radicalism in
France', in Art History, 1/1978, pp. 424 ff; especially pp. $431 \mathrm{f}$.

9 T. Puttfarken, 'David's Brutus and the Theories of Pictorial Lnity in France', in Art History, 3/1981, pp. 291 ff.

10 .M.-A. Laugier, Manière de bien juger les ouvrages de peinture, 1771. reprint Geneva, 1972, p. 84: 'Que se propose la peinture? sinon de nous donner une représentation de la chose assez vraisemblable pour que l'esprit se prenne au piège donné dans lillusion \& croit voir la réalité même.'

11 D. Diderot, Salons, vol. I, Oxford, 1957, pp. 240ft., p. 241: 'Et ce vide énorme qui sépare Ulỳsse de la scène et qui relc̀gue à une distance choquante? Il coupe la composition en deux parties dont on ferait deux tableaux distincts: l'une à conserver précieusement; l'autre à jeter au feu car elle est détestable.'

12 J. David, Le Peintre Louis David, 1748-1825. Souvenirs et Documents Irédits, Paris, 1880, p. 655.

13 This has been shown by Puttfarken (see note 9).

14 Fundamental for the notion of fiction: A.C. Quatremère de Quincy, Essai sur la nature, le but et les moyens de l'imitation dans les beaux-arts, Paris, 1823, e.g. p. 103.

15 Sprigath, op. cit. (note 4), p. 358.

16 Ibid., p. 346.

17 Ibid., p. 347.

18 N. Bryson, Word and Image. French Painting of the Ancien Régime, London/New York, 1981, p. 238.

19 D. Diderot, 'Paradoxe sur le comédien', in Oeuvres Esthétiques (ed. Vernière), Paris, 1959, 
especially pp. 304, 306ft. and passim.

20 R.L. Herbert, David. Voltaire, Brutus and the French Revolution - an essay in art and politics, London. 1972. p. 51.

21 Quoted in Sprigath. op. cit. (note +). p. 3.51.

22 For the relationship between enlightenment and politics of. Koselleck, op. cit. (note 2), especially chapter IV, 'Die verborgene Wendung gegen den Staat', pp. 68ft.

23 Cf. W'. Kemp, 'Das Bild der Menge (17891830)". in Städel Jahrbuch. X.F. 4 (1973), pp $249 f$.

24 Collection Deloynes (Paris, Bibliothèque Nationale) no. 598 , p. 781 , vol. XXI.

25 Ibid.. no. 597, p. 758, vol. XXI

26 Ibid.. no. 598 , p. 181, vol. XXI.

$27 \mathrm{Cf}$ a similar observation concerning David's Leonidas in: T. Gachtgens, 'J.L. David, Leonidas bei den Thermoprlen', in Ideal und Wirklichkeil der bildenden Kunst im späten 18. Jhdt, (svmposium Frankfurt, 1982) (= Frankfurter Forschungen sur Kunst, vol. XI, Berlin, 1984), pp. $231 \mathrm{ff}$.

$28 \mathrm{Cf}$. the repeated reproach of lack of action concerning Tatius and Romulus in Coll. Deloynes no. 597, p. 7\$9. vol. XX1 etc.

29 Ibid.. no. 597, p. 756, vol. XXI.

30 Published in D. Wildenstein, Documents Complementaires au Calalogue de l'oeuvre de L. David. Paris. 1973 , p. 138.

31 A.C. Quatremère de Quincy, Encyclopédie méthodique d'Architecture, Paris 1788, ff., vol. I. article 'antique', pp. $47 \mathrm{fl}$. Here we are confronted with the renunciation of the ontological conception of antiquity, which had made its totality into an ideal of perfection. When antiquity became historically understood. the work of art appeared not as a part of the totality of antiquity but obtained a purely aesthetic character.

32 Coll. Deloynes, no. 595, p. 677, val. XXI.

33 Ibid., no. 596 , p. 703 , vol. XX1.

34 Ibid., no. 598, p. 786, vol. X.Xr.

35 Ibid., no. 595, p. 676, vol. XXI.

36 David had come to know Winckelmann's work during his first stay in Rome.

37 J.J. Winckelmann, Geschichte der Kunst des Altertums, Dresden, 1764 ; reprinted Baden-Baden, 1966, p. 167.

38 J.J. Winckelmann, Sämtliche lierte in 13 Bänden, s.1. 1825, vol. IV, p. 192. This paragraph does not appear in the 1764 edition.

39 'Das allgemeine vorzügliche Kennzeichen der griechischen Meisterstücke ist . . . eine edle Einfalt, und eine stille Größe, sowohl in der Stellung als auch im Ausdrucke. So wie die Tiefe des Meeres alle Zeit ruhig blcibt, dic Oberfläche mag noch so wüten, ebenso zeigt der Ausdruck in den Figuren der Griechen bei allen Leidenschaften eine große und gesetzte Seele.' Quoted in J.J. Winckelmann, Gedanken über die Nachahmung der griechischen Werke in der. Malerei und Bildhauerkinst, Stuttgart, 1969, p. 20.

40 Cf. Wildenstein, op. cit. (note 30), p. 148.

41 Ibid.

42 G.-M. Raymond, De la peinture considérée dans ses effets sur les hommes en général el de son infuence sur les moeurs et le gouvernement des peuples. Paris. An Vil.

43 This is confirmed by the remark of a critic who greeted David's Sabines as a step away from the mud of politics. Cf. Coll. Deloynes, no. 601, p. 815 , vol. XXI. 


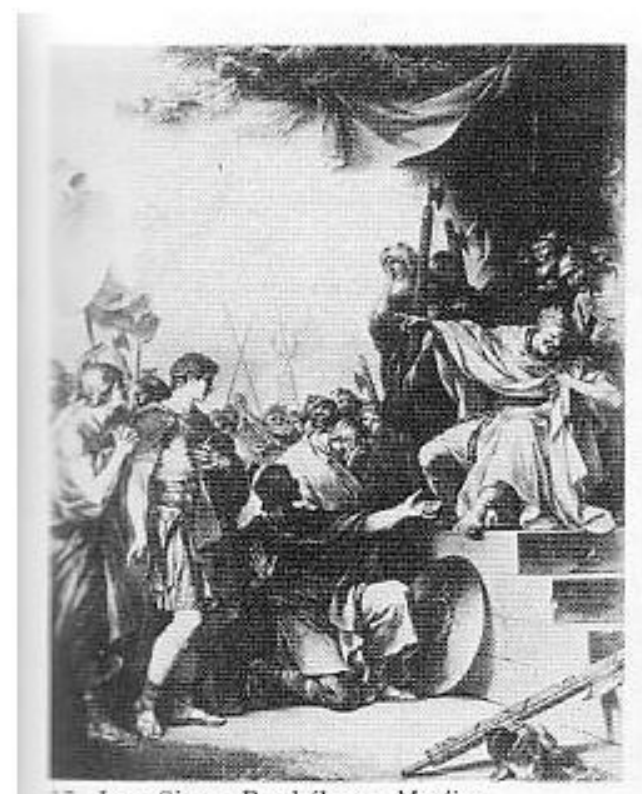

17. Jean-Simon Berthélemy, Manlius

Torquatus who condenins his Son to Denlh, Salon of 1785, Musece de Tours

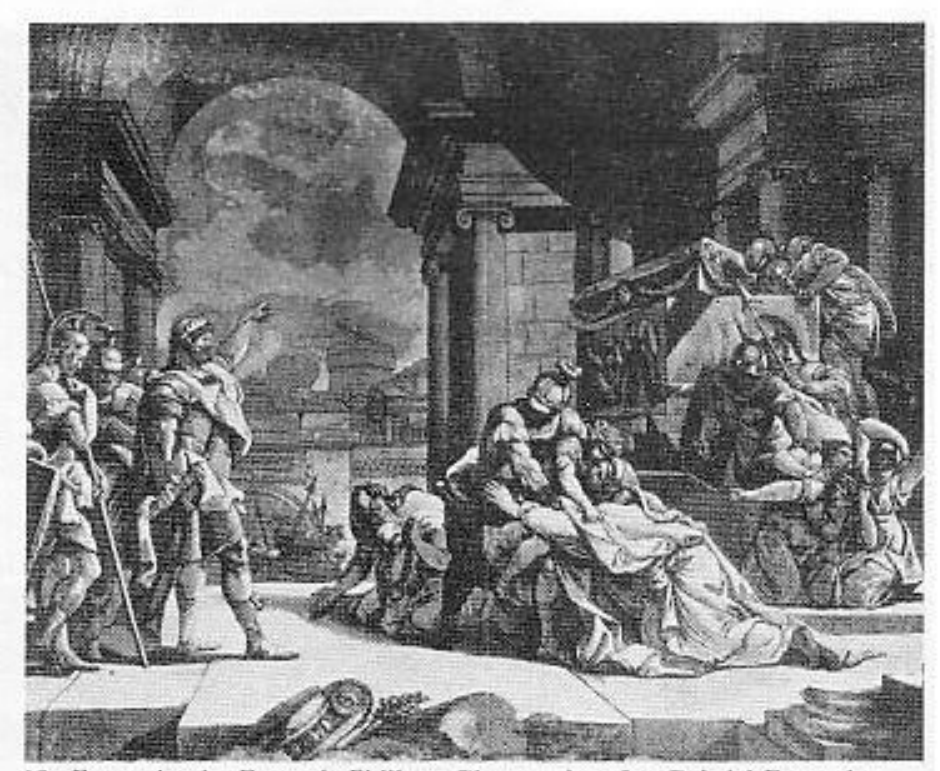

18. Engraving by François-Philippe Charpentier after Gabriel-François

Doyen, Ulyses and Andromache, Salon of 1763

19. Jacques-L auis David, Brutus and his Dead Sons, 1789, Paris, Louvre

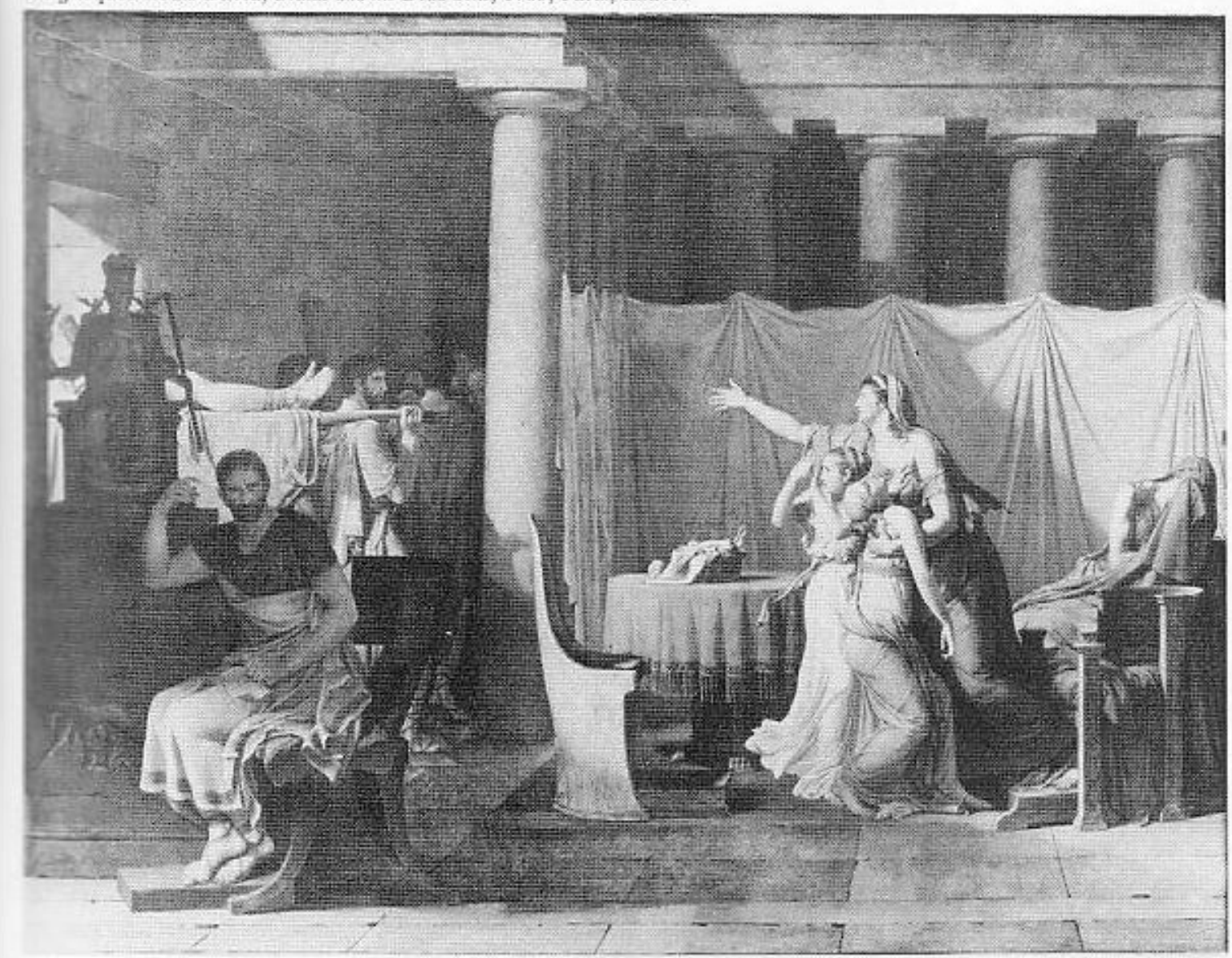




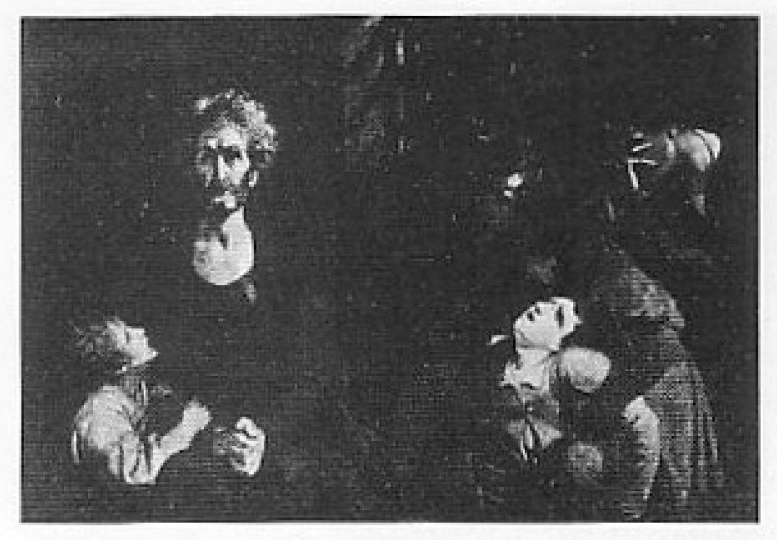

20. Sir Joshua Reynolds, Coanl Ugolino and his

Children in the Dungram, 1774 , Kinole, Kent
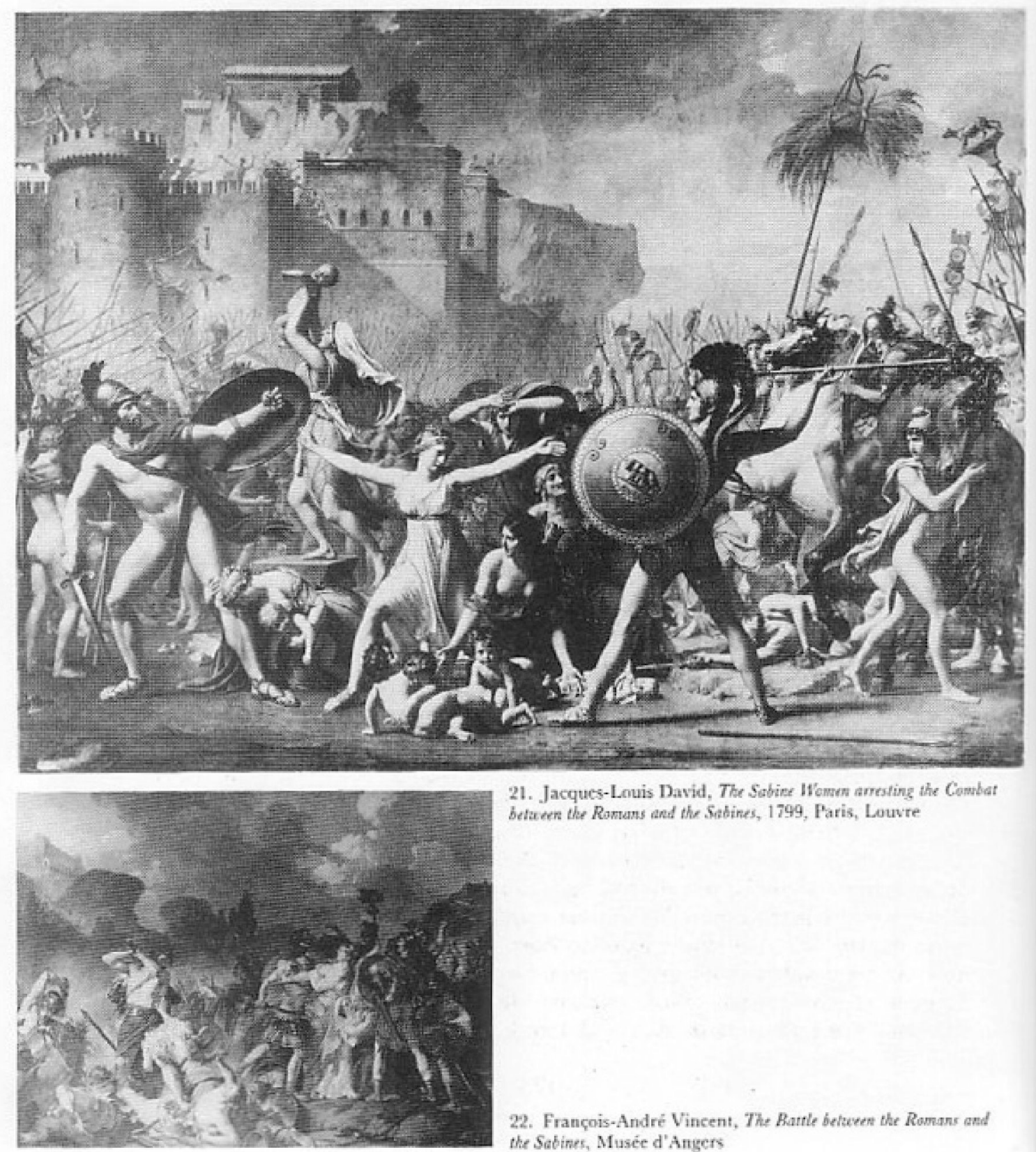

21. Jacques-Louis David, The Sobie Hown ameting the Combat betam the Ronans and the Sabines, 1799, Paris, Louvre

22. Francris-Andre Vincent, The Rante briwent the Rarang and the Sobines, Museed'Angers 